\title{
Measurements of ice thickness on glaciers at Isortuarssûp tasia, southern West Greenland and Pâkitsoq, central West Greenland
}

\author{
Leif Thorning and Egon Hansen
}

Two separate geophysical projects were carried out in 1988 as part of glacier-hydrological investigations of the margin of the Inland Ice. We made a reconnaissance electromagnetic resonance survey over the ice margin adjacent to Sermilik and Isortuarssûp tasia, south-east of Nuuk/Godthåb and measured ice thickness along some lines in the area of Qamanârssûp sermia, Kangiata nunâta sermia and Kangaussarssup sermia a short distance to the north, as well as a few profiles over a local ice cap just east of Isortuarssûp tasia. In the Pâkitsoq area, north east of Ilulissat/Jakobshavn, we finished the mono-pulse ice radar work started last year (Thorning \& Hansen, 1988a).

\section{EMR surveys in the Isortuarssûp tasia area}

In April 1988 an EMR survey was carried out over a part of the Inland Ice margin at Sermilik and Isortuars- sûp tasia (fig. 1). The survey area will be a potential reserve basin if a hydropower plant is built at Buksefjorden to supply power to Nuuk and thus it is necessary to collect information on subglacial relief of this part of the Inland Ice.

The operation was based on Nuuk Airport. A Bell 206 helicopter with floats from Greenlandair Charter $\mathrm{A} / \mathrm{S}$ (OY-HBF) was used as in previous years in the Pâkitsoq surveys, and the same $300 \mathrm{mHz}$ radar equipment was installed with the parabolic antenna between the floats (Thorning et al., 1986; Thorning \& Hansen, 1987,1988 b). No special navigation equipment was used. Ice thicknesses were measured in three long days of operation. The work over Qamanârssûp sermia (fig. 2) was undertaken in one day. The work over the local ice field (fig. 3) was carried out directly from Nuuk. Aircraft and instruments worked without any problems for the duration of the survey.
Fig. 1. Flight line map of the EMR survey at Isortuarssûp tasia. A total of $773 \mathrm{~km}$ were acquired in 49 profiles. The asterisk shows the position of mono-pulse ice radar measurements confirming an ice thickness of $80-100 \mathrm{~m}$.

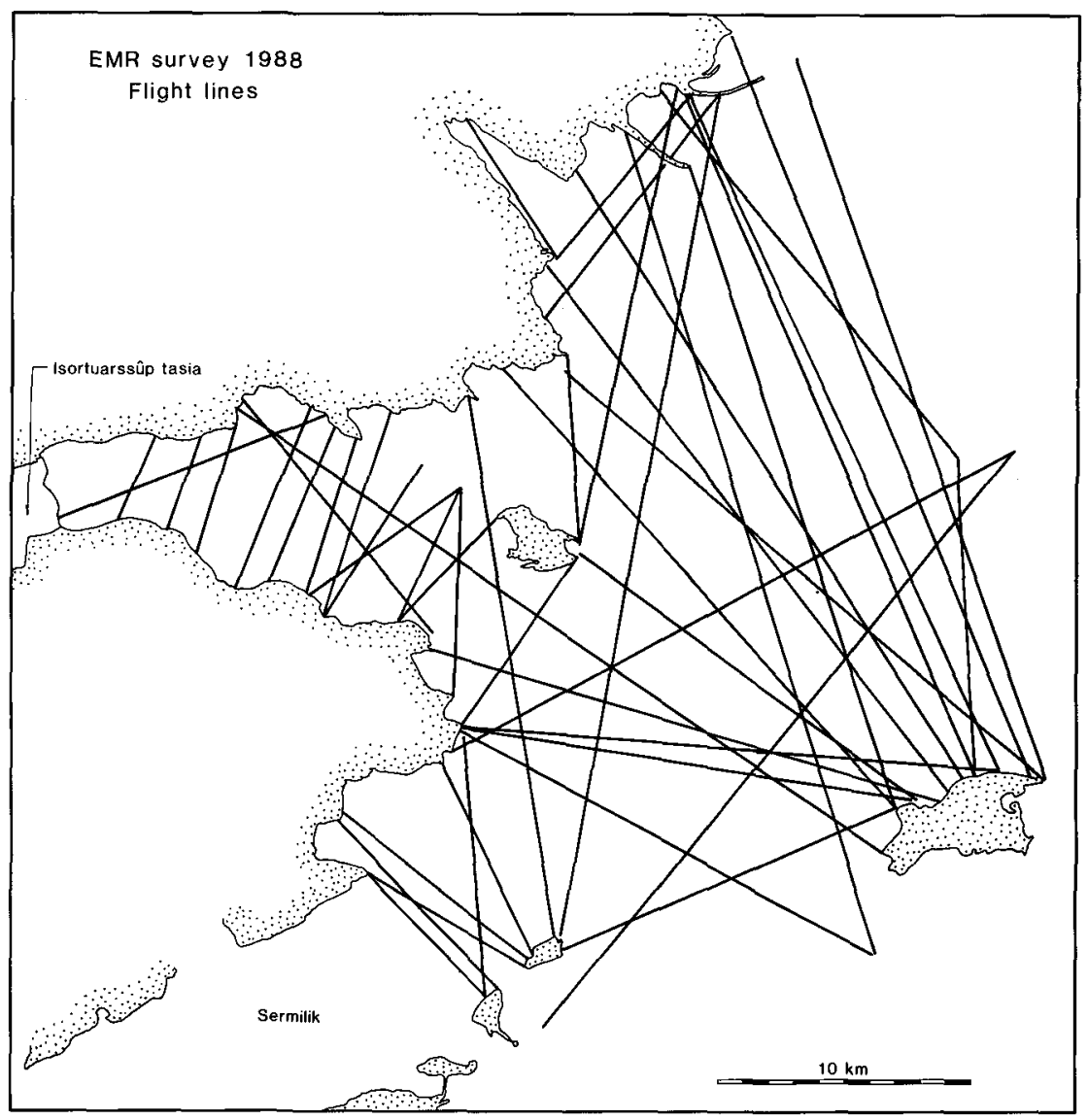




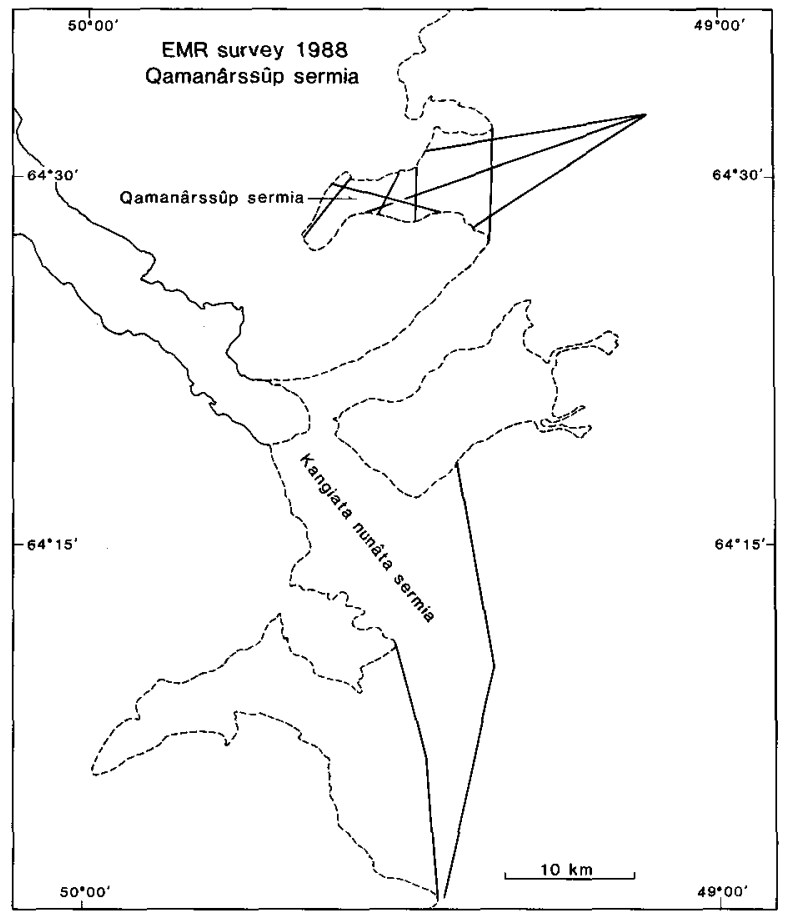

Fig. 2. Reconnaissance lines at Qamanârssûp sermia (133 km).

As in previous years, the flight altitude was kept as low as possible, depending on the character of the ice surface; over smooth ice the altitude was less than $10 \mathrm{~m}$; over crevassed areas sometimes a little higher. The many nunataks in the area made it possible to fly all lines by visual navigation, using aerial photographs. Altogether 961 line kilometres were acquired, 773 in the main survey area, 133 over Qamanârssûp sermia and 55 over the local ice field.
Already in the field it was obvious that despite good operating conditions and well-functioning instruments, the data recovery would not be as complete as in the Pâkitsoq area. Whereas at Pâkitsoq, good reflections were obtained over $70-80 \%$ of the distance flown, the figure is around $20 \%$ in the Isortuarssûp tasia area. The reflections from the subglacial surface were few and scattered, and in many areas no signal at all came through. The reasons for this are not obvious, but apparently the character of the ice is less favourable for the propagation of electromagnetic waves than the ice at Pâkitsoq. For example, much of the energy seemed to be reflected at the surface. In the few areas where this was not the case, reflections from deeper horizons could usually be recorded. Part of the problem may be that the ice thickness is apparently very shallow with reflections at around 1-2 microseconds over large areas. This was confirmed in one area (fig. 1) by a few mono-pulse radar measurements from the ice surface. This means that the 'false reflection' around 1 microsecond, caused by the change from reduced sensitivity of the receiver just after the transmission of the signal to its full sensitivity, to some extent masks the early reflections from the rock closely beneath the ice. It is therefore important that the photographs of stacked data (intensity trace') are as clear and well defined as possible. For that reason a new $Z$-amplifier was used in the production of EMR sections, and it has resulted in increased clarity of the recordings so that in several cases it is possible to follow bottom reflections up through the 'false' reflection.

The EMR data are at present (September 1988) being digitized and compiled into a data base of ice thickness, to be gridded where possible. The flight lines have been

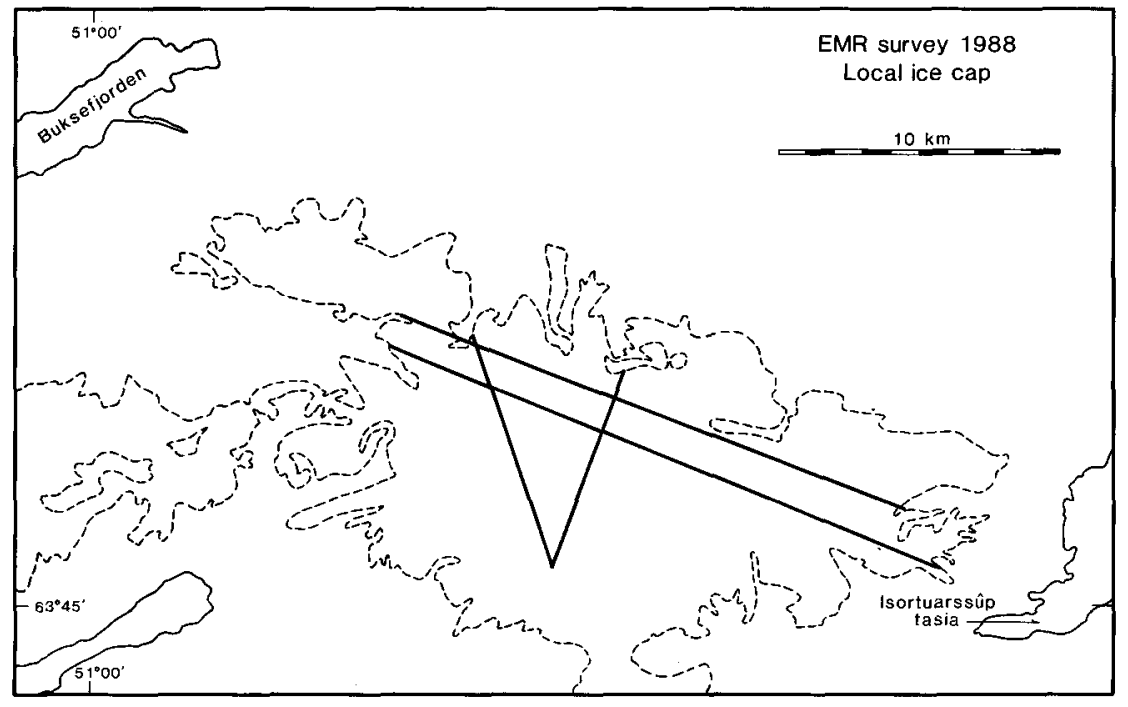

Fig. 3. Reconnaissance lines (55 km) over local ice cap just west of Isortuarssûp tasia. 


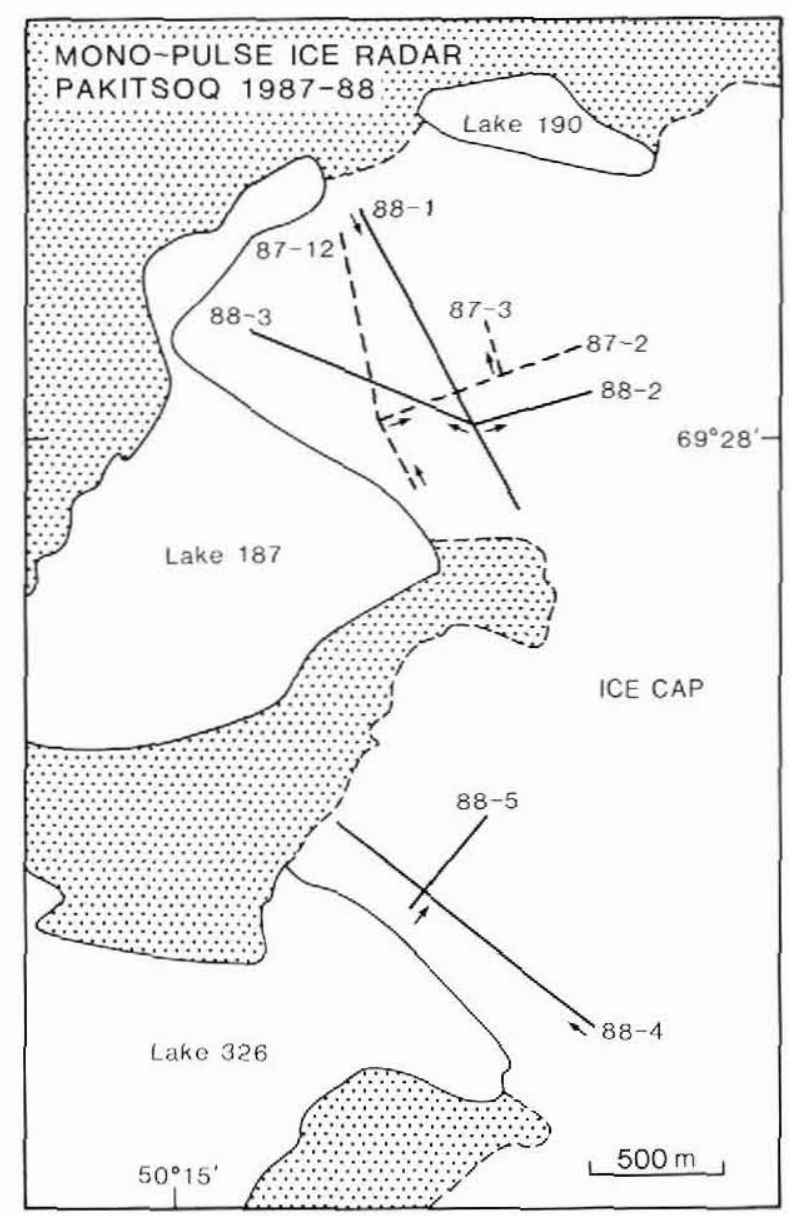

Fig. 4. Mono-pulse ice radar profiles 1987 and 1988 at Pâkitsoq. The interpreted ice thicknesses are shown in fig. 6 where the origin of the horizontal coordinate corresponds to the arrows on this line map. plotted on 1:100 000 maps from the area and digitized. The contours of the topography of the ice surface have been digitized $(1: 20000)$ where they exist. In areas where no information exists an approximate measure of topographic height was obtained using the helicopter altimeter, calibrated over known terrain. On the basis of these data a grid of topographic heights will be calculated, and the two grids of surface and ice thickness will then be used for the calculation of the subglacial topography.

The lines flown in the area north of the main Isortuarssûp tasia area, especially over Qamanârssûp sermia, obtained some good reflections over reasonably smooth ice, but very few reflections over crevassed areas, such as the lower parts of the glacier itself.

A few lines were flown over a local ice field in the area to test if the equipment could be used in such areas, as very little is known about the many small, local ice fields of Greenland. It was possible to obtain airborne EMR data over the local ice field selected for this experiment, although it was a more difficult operation than over the Inland Ice itself, because of rapidly changing topography, short lines, navigational difficulties, turbulence and generally difficult flying conditions. The interpretation of the limited amount of EMR data will also be more difficult for these reasons and because of reflections from numerous tops and crags in the area. We suggest that future operations in this or similar areas should be based on ground work using the EMR equipment on a sledge, perhaps with a frequency of $60 \mathrm{mHz}$, in a net laid out in an optimal manner and supplemented by mono-pulse ice radar measurements in areas with thin ice.
Fig. 5. Example of photograph of mono-pulse ice radar data (line 88-6). Scales are $0.5 \mu$ second $/$ div. (horizontal) and $50 \mathrm{mV} /$ div. (vertical).

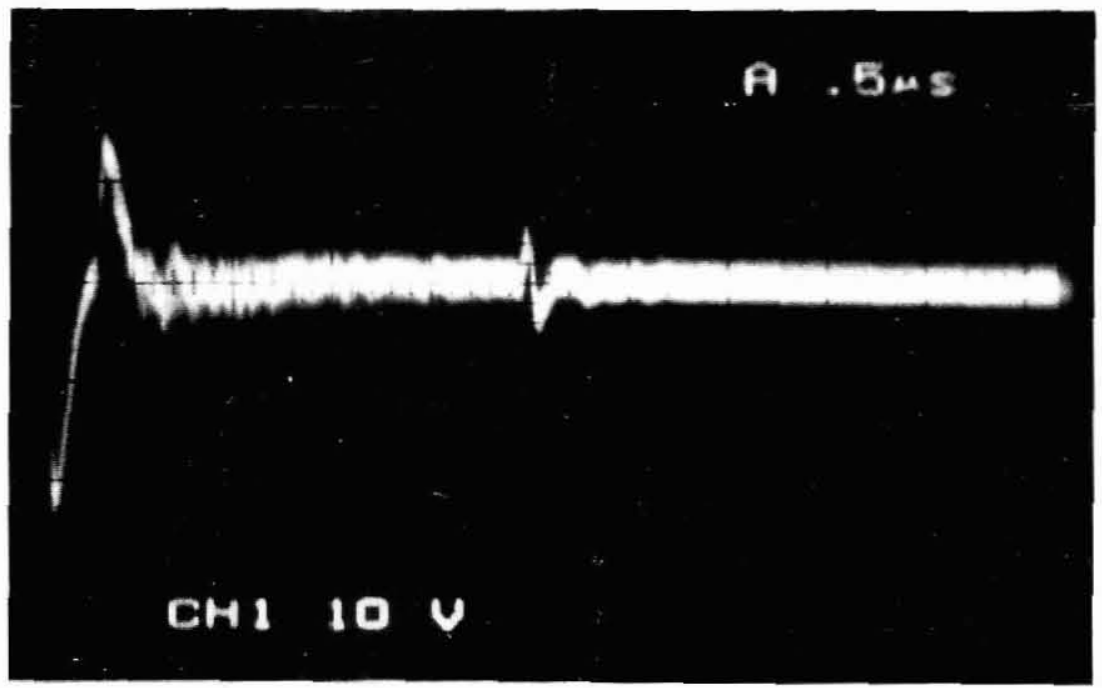



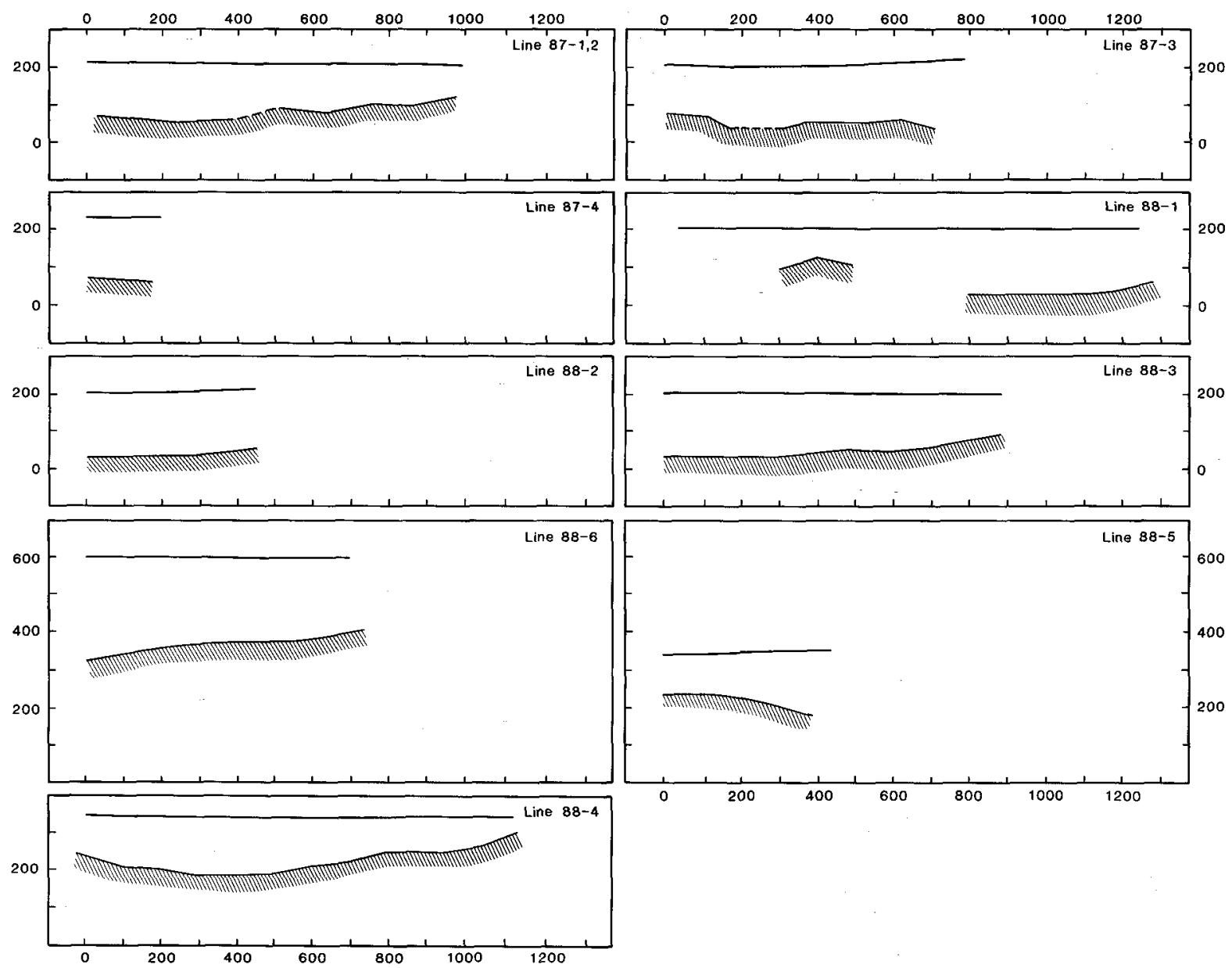

Fig. 6. Interpreted depth-profiles based on mono-pulse ice radar measurements, showing ice surface (approximately for lines $88-5$ and 88-6) and ice/rock interface. The zero horizontal coordinate of each line is indicated by an arrow on the line map in fig. 4.

\section{Mono-pulse ice radar measurements in the Pâkitsoq basin}

During a five-day operation in August 1988 we obtained new data on the ice thickness of the lowermost parts of the glaciers draining into $\$ \emptyset 326$ and $S \varnothing 187$, and on the Inland Ice itself near the ice camp (fig. 4). The logistics of the operation was based on the GGU base camp at Atâ (Kalsbeek, 1989) and the GGU camp on the ice (Thomsen et al., 1989). From a tent camp on the slopes just north of Sø 187, we could reach most of the glacier and needed only short helicopter lifts to the more distant work areas. Most of the lines were measured by the two authors, but one line (88-6) was done with the extra help of one assistant, which in effect doubled the production.

The equipment tested last year (Thorning \& Hansen, 1988a) has been improved significantly. In the transmit- ter the high voltage power supply now works much better. The receiver has been fitted with a differential amplifier which stabilizes the signal and consequently improves the resolution of the photographs taken of the oscilloscope screen. All lines are measured with antenna half-length $10 \mathrm{~m}$ corresponding to $5 \mathrm{mHz}$, and a transmitter-receiver distance of $90 \mathrm{~m}$ (88-1 to 88-5) or $100 \mathrm{~m}(88-6)$. Fig. 5 shows an example from one of the measurements performed near the ice camp (line 88-6). The reflection is well defined, and the reversal of the phase, generally considered consistent with reflection from an ice/rock interface, can be seen.

The two-way-travel-times were measured on such photographs and the data were treated as explained in Thorning \& Hansen (1988a). Fig. 6 shows the interpreted depth profiles, including the three lines acquired in 1987. All data points will be included in the data base of ice thicknesses in the area. 
Acknowledgements. We would like to express our appreciation of the excellent work of the pilots from Greenlandair A/S during the EMR survey at Isortuarssûp tasia, and the logistic support by the GGU base camp at Atâ and the camp on the ice. Much of the computer treatment of these data was undertaken by Mette Svane Jørgensen and Dorthe Nyland Sørensen, GGU.

\section{References}

Kalsbeek, F. 1989: GGU's expedition in the Disko Bugt area, 1988. Rapp. Gronlands geol. Unders. 145 (this volume).

Thomsen, H. H., Olesen, O. B., Braithwaite, R. J. \& Weidick, A. 1989: Greenland ice-margin programme, a pilot study at Pâkitsoq, north-east of Jakobshavn, central West Greenland. Rapp. Grønlands geol. Unders. 145 (this volume).

Thorning, L., Thomsen, H. H. \& Hansen, E. 1986: Geophysical investigations at the Inland Ice margin of the Pâkitsoq basin, central West Greenland. Rapp. Grønlands geol. Unders. 130, 114-121.

Thorning, L. \& Hansen, E. 1987: Electromagnetic reflection survey 1986 at the Inland Ice margin of the Pâkitsoq basin, central West Greenland. Rapp. Grønlands geol. Unders. 135, 87-98.

Thorning, L. \& Hansen, E. 1988a: Construction and testing of a lightweight radar for ice-thickness determination on glaciers in the Pâkitsoq area, central West Greenland. Rapp. Gronlands geol. Unders. 140, 118-121.

Thorning, L. \& Hansen, E. 1988b: Electromagnetic reflection survey 1987 in key areas of the Pâkitsoq basin at the margin of the Inland Ice, central West Greenland. Rapp. Grønlands geol. Unders. 140, 117-118.

L. T. \& E. H., Grønlands Geologiske Undersøgelse, $\emptyset$ ster Voldgade 10 , $D K-1350$ København $K$, Danmark.

\title{
Improved accumulation measurements on Glacier 1CG14033 near Nuuk/Godthåb, West Greenland
}

\author{
Roger J. Braithwaite and Henrik Højmark Thomsen
}

Glacier 1CG14033 is a small $\left(1.1 \mathrm{~km}^{2}\right)$ glacier located in the Kangerluarsunnguaq or Buksefjorden basin, which is a possible site for a hydropower station to supply energy to Nuuk/Godthåb (fig. 1). Glaciers only occupy $1-2 \%$ of the basin area (Weidick \& Thomsen, 1983), but glaciological measurements have been made since 1982 to investigate the possible effects of glaciers on runoff and to contribute to GGU's programme of regional glaciology.

\section{Measurements 1982-1987}

Eight aluminium stakes were drilled into the glacier in 1982 and have been used for rudimentary mass-balance measurements during twice-yearly visits of a few hours by helicopter. The winter snow accumulation is determined in May by measuring snow depths at all stakes and measuring snow density in snowpits of 1-3 m depth at some stakes. The summer ablation is determined in late August or early September at the lowest stakes by measuring the lowering of the ice surface relative to the stakes. However, snow ablation at higher stakes is more difficult to measure as most water from snow melt refreezes at depth in the snowpack, possibly a few metres below the surface. Brief twice-yearly visits made in the period 1982-1987 never allowed time to dig or core throughout the whole wet snow layer. With the reduction in activity at Qamanârssûp sèrmia since 1986 (Braithwaite, 1987) it was possible to plan a longer stay on the glacier in May 1988 to improve the accumulation measurements.

\section{The 1988 measurements}

A lightweight camp was established on the glacier as a base for the measurements in the period 5-8 May 1988. Camping equipment was as light as possible to allow a single flight with a Bell-206 Jet Ranger helicopter but was inadequate at temperatures of $-20^{\circ} \mathrm{C}$. Future operations will need at least two helicopter flights to establish camp.

A total of three deep snow pits were dug for density measurements, which is a great improvement on earlier years. Another improvement, although time-consuming, was the use of a GEOTEST ramsonde to measure hardness profiles in the snowpack. The hard 'summer surface' of 1987 could be more easily detected in this way than by using the standard GGU snow probe as in previous years.

Unfortunately only a brief visit could be made on 23 August to make stake readings adequate for calculating net ablation at stakes 1,2,4 and 7, but there was not enough time to measure the density profiles at stakes 5 , 6 and 8 , which are needed to calculate net ablation. It is 